\title{
Asupan natrium dan kalium berhubungan dengan frekuensi kekambuhan sindrom dispepsia fungsional
}

\author{
Hervina Dwijayanti ${ }^{1}$, Neneng Ratnasari ${ }^{2}$, Susetyowati ${ }^{3}$
}

\begin{abstract}
Background: A high-salt diet is known to cause gastritis, has been associated with a high risk of atrophic gastritis, and is considered a gastric tumor promoter. Excessive $\mathrm{NaCl}$ intake enhances Helicobacter pylori colonization in mice and in humans and that chronic salt intake may exacerbate gastritis by increasing Helicobacter pylori colonization. Furthermore, elevated salt intake may potentiate Helicobacter pylori-associated carcinogenesis by inducing proliferation, pit cell hyperplasia, and glandular atrophy.

Objective: The aim of this research was to describe the correlation between sodium and potassium intake and relapse frequent functional dyspepsia syndrome in Sardjito Hospital Yogyakarta.

Method: This was an observational research with cross sectional design. The subjects of this research were 32 course care patients in Sardjito Hospital Yogyakarta on November 2006-Januari 2007 who met the inclusion criteria. Those were who diagnosed as functional dyspepsia, with or without Helicobacter pylori infection, and above eighteen years old. Data were collected by interviewing and gathered from medical record, then analyzed using Rank-Spearman test.

Results: The average of the relapse frequent of dyspepsia syndrome in Sardjito Hospital was 14.38 \pm 2.93 , with the minimum score was 4 and the maximum score was 32 . The result showed that sodium intake gave a positive relation and significant for relapse frequent of dyspepsia syndrome $(p<0.05)$. The potassium intake gave a negative relation and significant for relapse frequent of dyspepsia syndrome $(p<0.05)$.

Conclusion : There was a positive and significant correlation between sodium intake and relapse frequent of dyspepsia syndrome, but there was a negative and significant correlation between potassium intake and relapse frequent of dyspepsia syndrome.
\end{abstract}

KEY WORDS sodium, potassium, functional dyspepsia syndrome

\section{PENDAHULUAN}

Dispepsia merupakan istilah yang sering dipakai pasien untuk menjelaskan sejumlah gejala yang umumnya dirasakan sebagai gangguan perut bagian atas dan gejala tersebut sering muncul berkaitan dengan asupan makan (1). Dispepsia fungsional adalah dispepsia kronis atau berulang, berlangsung lebih dari satu bulan, dan sedikitnya selama $25 \%$ dalam kurun waktu tersebut gejala dispepsia muncul. Tidak ditemukan penyakit organik yang bisa menerangkan gejala tersebut secara klinis, biokimiawi, endoskopi (tidak ada ulkus, tidak ada oesophagitis, dan tidak ada keganasan), atau radiografi (2).

Prevalensi dispepsia bervariasi dan sangat tergantung pada populasi. Prevalensi tersebut dapat menggambarkan perbedaan epidemiologi yang sesungguhnya dan menunjukkan berbagai definisi yang digunakan pada populasi yang berbeda sehingga menghasilkan prevalensi yang tidak sesuai. Prevalensi dispepsia fungsional secara global mencapai antara $11-29,2 \%$ (3). Di Indonesia, tidak ada data yang pasti mengenai jumlah insidensi dispepsia fungsional. Laporan rawat jalan di RSUP Dr. Sardjito menjelaskan bahwa lebih dari $40 \%$ kasus per tahun yang datang dengan keluhan dispepsia (4).
Diet tinggi garam pada manusia dan hewan coba telah diketahui dapat mengakibatkan terjadinya peningkatan proliferasi epitel lambung, sehingga dapat menyebabkan gastritis yang mempunyai hubungan dengan tingginya risiko gastritis atropik dan merupakan promotor tumor lambung. Selain itu, konsumsi $\mathrm{NaCl}$ dalam jumlah yang berlebihan akan meningkatkan kolonisasi Helicobacter pylori pada tikus dan manusia. Asupan garam berlebihan secara terus menerus akan meningkatkan hiperplasia sel sehingga meningkatkan kolonisasi Helicobacter pylori. Infeksi Helicobacter pylori yang predominan di antrum dapat meningkatkan kadar gastrin sehingga dapat meningkatkan sekresi asam lambung dan menyebabkan tukak lambung (5).

Garam tidak berperan secara langsung sebagai zat karsinogenik, tetapi dapat meningkatkan risiko kanker lambung melalui kerusakan langsung mukosa lambung,

\footnotetext{
Instalasi Gizi RS Paramita, Kawasan Industri CCM, Jl. Raya Serang km 28,5 Kav F1-8, Balaraja, Tangerang, Banten, e-mail: hervinadwijayanti@yahoo.com

2 Bagian Penyakit Dalam RSUP Dr. Sardjito, Jl. Kesehatan, Yogyakarta

3 Instalasi Gizi RSUP Dr. Sardjito, Jl. Kesehatan, Yogyakarta, e-mail: susetyowati2000@yahoo.com
} 
yang dapat mengakibatkan gastritis, meningkatkan sintesis DNA, dan proliferasi sel. Gastriris ringan dapat menjadi gastritis kronis yang merupakan prekursor perlukaan lambung yang pada akhirnya dapat mengakibatkan kanker lambung. Garam tidak hanya meningkatkan sifat kimia zat karsinogenik di lambung, tetapi juga meningkatkan kolonisasi Helicobacter pylori yang merupakan penyebab kanker lambung, baik pada manusia maupun hewan (6).

Penelitian ini bertujuan untuk mengetahui hubungan antara asupan natrium dan kalium dengan kekambuhan dan infeksi Helicobacterpylori pada penderita sindrom dispepsia fungsional di Poliklinik Penyakit Dalam RSUP Dr. Sardjito Yogyakarta.

\section{BAHAN DAN METODE}

Penelitian ini merupakan penelitian observasional dengan pendekatan rancangan potong lintang. Penelitian ini dilaksanakan di Poliklinik Penyakit Dalam RSUP Dr. Sardjito Yogyakarta pada bulan November 2006-Januari 2007.

Populasi penelitian adalah seluruh pasien yang didiagnosis sebagai dispepsia fungsional oleh dokter ahli penyakit dalam di Poliklinik Penyakit Dalam RSUP Dr. Sardjito Yogyakarta pada bulan November 2006-Januari 2007 , sedangkan jumlah sampel penelitian yang dihitung dengan tingkat kepercayaan $90 \%$ yaitu 32 pasien (7) dan diambil secara purposive yang memenuhi kriteria inklusi dan eksklusi. Kriteria Inklusi meliputi: pasien yang didiagnosis sebagai dispepsia fungsional oleh dokter ahli penyakit dalam sesuai kriteria Roma II di Poliklinik Penyakit Dalam RSUP Dr. Sardjito Yogyakarta, dengan atau tanpa infeksi Helicobacter pylori, berumur $\geq 18$ tahun, dan bersedia menjadi sampel penelitian. Kriteria eksklusi meliputi: pasien dengan dispepsia organik atau gastropati OAINS, mengalami perdarahan lambung, dan gangguan berkomunikasi.

Asupan natrium diukur dengan menggunakan ratarata asupan per hari dari 93 macam makanan yang mengandung natrium dengan menggunakan kuesioner frekuensi makanan, termasuk konsumsi garam dapur $(\mathrm{NaCl})$ dalam satuan $\mathrm{mg} /$ hari. Asupan natrium dikelompokkan menjadi cukup ( $<2.400 \mathrm{mg} / \mathrm{hari}$ ) dan lebih $(\geq 2.400 \mathrm{mg} / \mathrm{hari})(8,9)$. Asupan kalium diperoleh dengan menggunakan kuesioner frekuensi makanan untuk mengetahui kebiasaan responden mengkonsumsi bahan makanan sumber kalium (mg/100 g bahan). Asupan kalium dikelompokkan menjadi cukup ( $\geq 2.000 \mathrm{mg} / \mathrm{hari})$ dan kurang (<2.000 mg/hari) (8).

Kekambuhan sindroma dispepsia fungsional merupakan frekuensi keluhan yang dirasakan sampel selama dua minggu terakhir. Berdasarkan keluhan-keluhan yang dirasakan sampel, dispepsia fungsional dibagi atas $(10,11,2)$ :
Dysmotility-like dyspepsia dengan keluhan perasaan tidak enak di perut yang bertambah sakit setelah makan, dengan satu atau lebih gejala yang lain seperti cepat kenyang, kembung, bersendawa, mual atau muntah. Biasanya mual didapat pada waktu bangun pagi, juga kadang-kadang disertai muntah.

Ulcer-like dyspepsia dengan keluhan penderita menyerupai tukak peptik dengan gejala yang menonjol adalah nyeri di epigastrium yang terlokalisir, nyeri waktu malam hari, atau pada saat perut kosong dan terjadi perbaikan bila makan atau minum antasida bahkan kadangkadang menunjukkan pola remisi dan relaps.

Reflux-like dyspepsia dengan gejala yang menonjol adalah selain rasa terbakar atau rasa tidak enak di belakang sternum atau epigastrium juga regurgitasi asam dan makanan yang timbul sesudah makan.

Non-specific dyspepsia yang tidak ditandai dengan gejala menonjol, sehingga sulit untuk dikelompokkan pada tiga kelompok di atas.

Adapun skoring kekambuhan berkisar antara 0-40 (skala rasio). Frekuensi kekambuhan meliputi: skor 0 bagi yang tidak ada keluhan, 1 apabila terjadi kekambuhan satu sampai empat hari, 2 apabila terjadi kekambuhan lima sampai delapan hari, 3 apabila terjadi kekambuhan sembilan sampai dua belas hari, dan 4 apabila terjadi kekambuhan > dua belas hari (hampir setiap hari).

Status gizi diukur berdasarkan berat badan dan tinggi badan yang masing-masing diukur dengan timbangan injak digital berketelitian $0,01 \mathrm{~kg}$ dan microtoise berketelitian $0,1 \mathrm{~cm}$. Data mengenai diagnosis responden (tipe dispepsia dan hasil pemeriksaan Helicobacter pylori) diperoleh dari catatan diagnosis pada buku status pasien di Poliklinik Penyakit Dalam RSUP Dr. Sardjito Yogyakarta. Diagnosis Helicobacter pylori ditegakkan dengan pemeriksaan invasif yaitu dengan metode kultur biopsi dengan mengambil material biopsi dari mukosa gaster dengan endoskopi.

Analisis untuk mengetahui hubungan antara asupan natrium dan kalium dengan frekuensi kekambuhan sindrom dispepsia menggunakan analisis korelasi RankSpearman.

\section{HASIL DAN BAHASAN}

\section{Karakteristik sampel penelitian}

Karakteristik sampel penelitian meliputi: jenis kelamin, umur, pendidikan, etnis, IMT, tipe dispepsia, dan infeksi Helicobacter pylori (Tabel 1).

Berdasarkan jenis kelamin, sampel laki-laki dan perempuan berjumlah sama, masing-masing sejumlah $50 \%$ dan sebagian besar termasuk kategori dewasa $(80,65 \%)$ 
TABEL 1. Karakteristik sampel penelitian

\begin{tabular}{|c|c|c|}
\hline Karakteristik & Jumlah & Persentase (\%) \\
\hline \multicolumn{3}{|l|}{ Jenis kelamin } \\
\hline Laki-laki & 16 & 50 \\
\hline Perempuan & 16 & 50 \\
\hline \multicolumn{3}{|l|}{ Umur } \\
\hline Dewasa (18-65 tahun) & 25 & 78,1 \\
\hline Lansia ( $>65$ tahun) & 7 & 21,9 \\
\hline \multicolumn{3}{|l|}{ Pendidikan } \\
\hline SD & 3 & 9,4 \\
\hline SMP & 6 & 18,8 \\
\hline SMU & 11 & 34,4 \\
\hline Akademi & 4 & 12,5 \\
\hline S1 atau lebih & 8 & 25 \\
\hline \multicolumn{3}{|l|}{ Etnis } \\
\hline Jawa & 31 & 96,9 \\
\hline Lain-lain & 1 & 3,1 \\
\hline \multicolumn{3}{|l|}{ Status gizi } \\
\hline Kurang & 3 & 9,4 \\
\hline Normal & 25 & 78,1 \\
\hline Lebih & 4 & 12,5 \\
\hline \multicolumn{3}{|l|}{ Tipe dispepsia } \\
\hline Dysmotility & 15 & 46,9 \\
\hline Ulcer & 11 & 34,4 \\
\hline Non-specific & 6 & 18,8 \\
\hline \multicolumn{3}{|l|}{ Infeksi Helicobacter pylori } \\
\hline Positif & 0 & 0 \\
\hline Negatif & 7 & 100 \\
\hline
\end{tabular}

serta memiliki tingkat pendidikan akhir sekolah menengah umum (SMU) yaitu sebesar $34,375 \%$. Menurut etnis, hampir seluruh sampel $(96,875 \%)$ berasal dari etnis Jawa.

Berdasarkan status gizi, sebagian besar sampel $(80,65 \%)$ mempunyai status gizi normal. Berdasarkan tipe dispepsia, sebagian besar sampel $(46,875 \%)$ termasuk dalam kategori dysmotility-like dyspepsia.

Pada penelitian ini, sampel yang telah diperiksa infeksi Helicobacter pylori hanya 7 orang, namun di antara sejumlah tersebut tidak ada yang dinyatakan positif terinfeksi Helicobacter pylori.

\section{Hubungan asupan natrium dengan frekuensi kekambuhan sindrom dispepsia}

Distribusi asupan natrium sampel dapat dilihat pada Tabel 2. Sebagian besar sampel $(62,5 \%)$ mengkonsumsi natrium dalam jumlah yang berlebih ( $\geq 2.400 \mathrm{mg} / \mathrm{hari})$. Berdasarkan hasil uji Rank-Spearman diperoleh adanya hubungan positif dan bermakna antara asupan natrium dan frekuensi kekambuhan sindrom dispepsia $(p<0,05)$, namun kekuatan korelasi antara kedua variabel tersebut termasuk sedang $(r=0,450)$. Arah hubungan yang positif menunjukkan bahwa makin besar asupan natrium, makin besar pula frekuensi kekambuhan sindrom dispepsia.

Hasil penelitian ini sesuai dengan penelitian sebelumnya yang menyebutkan bahwa diet tinggi garam pada manusia dan hewan coba telah diketahui dapat menyebabkan gastritis yang mempunyai hubungan dengan tingginya risiko gastritis atropik dan merupakan promotor tumor lambung (5). Penelitian case-control yang lain menyebutkan bahwa terdapat hubungan yang bermakna antara meningkatnya risiko kanker lambung dengan meningkatnya konsumsi garam atau asupan natrium atau penggunaan garam meja (6).

Penelitian Tsugane (12) juga menyebutkan bahwa asupan garam berhubungan dengan risiko kanker lambung pada laki-laki, namun tidak menunjukkan kecenderungan yang jelas pada wanita. Pada penelitian tersebut terdapat hubungan yang lemah antara konsumsi sup miso, sayuran yang diawetkan, dan ikan kering dengan risiko kanker lambung, namun hubungan yang kuat ditunjukkan antara konsumsi makanan dengan kandungan garam yang tinggi, seperti ikan asin dengan risiko kanker lambung pada kedua jenis kelamin. Hubungan yang kuat antara makanan yang diasinkan dengan kanker lambung berkaitan dengan senyawa karsinogenik, nitrat atau nitrit selama proses pengawetan dan pencernaan dalam lambung.

Menurut Strumylaitë (6), garam tidak berperan secara langsung sebagai zat karsinogenik, tetapi dapat meningkatkan risiko kanker lambung melalui kerusakan langsung mukosa lambung yang dapat mengakibatkan gastritis, meningkatkan sintesis DNA, dan proliferasi sel. Gastriris ringan dapat menjadi gastritis kronis yang merupakan prekursor perlukaan lambung yang pada akhirnya dapat mengakibatkan kanker lambung.

\section{Hubungan asupan kalium dengan frekuensi kekambuhan sindrom dispepsia}

Distribusi asupan kalium sampel dapat dilihat pada Tabel 3. Sebagian besar sampel $(59,4 \%)$ termasuk dalam kategori kurang $(<2.000 \mathrm{mg} / \mathrm{hari})$. Berdasarkan hasil uji Rank-Spearman diperoleh hasil bahwa asupan kalium dan frekuensi kekambuhan sindrom dispepsia menunjukkan adanya hubungan negatif dan bermakna dengan kekuatan korelasi sedang $(r=-0,423 ; p<0,05)$. Koefisien korelasi negatif

TABEL 2. Distribusi asupan natrium

\begin{tabular}{ccccc}
\hline Asupan natrium (mg/hari) & Jumlah & Persentase (\%) & $\mathbf{r}$ & $\mathbf{p}$ \\
\hline$<2.400$ & 12 & 37,5 & 0,45 & $<0,05$ \\
$\geq 2.400$ & 20 & 62,5 & & \\
Total & $\mathbf{3 2}$ & $\mathbf{1 0 0}$ & & \\
\hline
\end{tabular}


TABEL 3. Distribusi asupan kalium

\begin{tabular}{ccccc}
\hline Asupan kalium (mg/hari) & Jumlah & Persentase (\%) & $\mathbf{r}$ & $\mathbf{p}$ \\
\hline$<2.000$ & 19 & 59,4 & $-0,423$ & $<0,05$ \\
$\geq 2.000$ & 13 & 40,6 & & \\
Total & $\mathbf{3 2}$ & $\mathbf{1 0 0 \%}$ & & \\
\hline
\end{tabular}

menunjukkan adanya hubungan yang berlawanan, sehingga makin besar asupan kalium, frekuensi kekambuhan sindrom dispepsia akan makin kecil.

Buah-buahan dan sayuran segar yang merupakan sumber kalium dapat menghambat pembentukan nitrat menjadi nitrosamin. $\mathrm{N}$-nitrosa ( $\mathrm{N}$-nitrosa compound) terbentuk dari makanan yang mengandung nitrat (makanan yang diasamkan, diasinkan, dan diasapkan). Nitrat di dalam lambung diubah menjadi nitrit, kemudian bereaksi sekunder atau tersier membentuk senyawa nitrosamin tersebut yang merupakan zat karsinogen (13).

Selain itu, buah-buahan dan sayuran merupakan sumber antioksidan yang dapat memberikan perlindungan terhadap tubuh, sehingga dapat menurunkan risiko terjadinya ulkus pada lambung dan meringankan gejala pada saat ulkus mulai terbentuk (14).

\section{Hubungan asupan natrium dan kalium dengan infeksi Helicobacter pylori}

Helicobacter pylori merupakan salah satu dari sejumlah besar bakteri patogen pada manusia yang hanya hidup dan berkoloni di dalam mukosa lambung. Kuman ini dapat bertahan hidup di dalam mukus (lendir) yang menutupi selaput lendir (mukosa) lambung yang bersifat asam karena kemampuan kuman ini dalam memproduksi urease. Kuman akan mati pada suasana dengan kadar oksigen normal atau anaerobik. Dalam keadaan tertentu yang kurang menguntungkan, kuman ini akan berubah menjadi kokoid yang resisten terhadap asam lambung (15).

Ada beberapa cara untuk mendiagnosis Helicobacter pylori, yaitu cara invasif dan noninvasif. Prosedur invasif terdiri atas: endoskopi dan biopsi mukosa, histologi, kultur mikrobiologi, dan uji urease cepat. Prosedur noninvasif meliputi uji serologi dengan darah, saliva, dan uji urea nafas (16). Di RSUP Dr. Sardjito, diagnosis Helicobacter pylori ditegakkan dengan pemeriksaan invasif yaitu dengan metode kultur biopsi dengan mengambil material biopsi dari mukosa gaster dengan endoskopi. Metode ini memerlukan waktu yang cukup lama dan biaya yang mahal.

Pada penelitian ini, sampel yang telah diperiksa infeksi Helicobacter pylori hanya 7 pasien. Hal ini berkaitan dengan metode yang digunakan yang bersifat invasif dan memerlukan biaya mahal. Karena keterbatasan tersebut, maka hubungan antara asupan natrium dan kalium dengan infeksi Helicobacter pylori tidak dapat dianalisis.
Penelitian cross-sectional sebelumnya pada 634 responden laki-laki berumur 40-49 tahun di Jepang menunjukkan adanya hubungan yang bermakna antara frekuensi asupan sayuran yang diawetkan dan sup miso dengan prevalensi antibodi IgG Helicobacter pylori. Asupan sayuran yang diawetkan dan sup miso merupakan indikator asupan makanan yang mengandung kadar garam tinggi. Penelitian ini menyimpulkan bahwa meningkatnya asupan makanan dengan kandungan garam yang tinggi dapat meningkatkan risiko infeksi Helicobacter pylori (17).

Konsumsi $\mathrm{NaCl}$ dalam jumlah yang berlebihan akan meningkatkan kolonisasi Helicobacter pylori pada tikus dan manusia. Asupan garam yang berlebihan berhubungan secara bermakna dengan proliferasi pada korpus proksimal dan antrum, serta berhubungan dengan penurunan jumlah sel parietal pada korpus proksimal sehingga dapat mengakibatkan terjadinya pemanjangan lubang dalam lambung. Asupan garam berlebihan secara terus menerus akan meningkatkan kolonisasi Helicobacter pylori sehingga dapat menyebabkan gastritis. Meningkatnya asupan garam dan infeksi Helicobacter pylori dapat berasosiasi sebagai karsinogenik dengan memacu proliferasi sel, hiperplasia sel, dan atropi glandular (5).

Bahan makanan yang mengandung sumber kalium seperti sayuran dan buah-buahan mengandung zat antioksidan yang dapat merangsang sistem imun tubuh untuk melawan radikal bebas yang membentuk karsinogen (substansi yang dapat menimbulkan kanker). Mekanisme antioksidan dalam menghambat terjadinya kanker ini termasuk mencegah pembentukan karsinogen dan menghalangi rusaknya sel normal lainnya. Pada percobaan terhadap binatang terbukti bahwa antioksidan mampu menghambat kerusakan kromosom, tahap promosi tumor, transformasi sel, dan rangsangan terbentuknya kanker secara kimia atau radiasi (11).

\section{KESIMPULAN DAN SARAN}

Terdapat hubungan positif dan bermakna antara asupan natrium dan frekuensi kekambuhan sindrom dispepsia dengan kekuatan korelasi sedang, namun antara asupan kalium dan frekuensi kekambuhan sindrom dispepsia ditemukan hubungan negatif dan bermakna dengan kekuatan korelasi sedang. Untuk itu diperlukan penelitian lebih lanjut mengenai hubungan antara asupan natrium dan 
kalium dengan frekuensi kekambuhan sindrom dispepsia dengan memperhatikan faktor-faktor lain yang merupakan risiko penyebab kekambuhan sindrom dispepsia, seperti kebiasaan merokok, konsumsi alkohol, dan faktor stres.

\section{RUJUKAN}

1. Friedman LS, Isselbacher KJ. Anoreksia, Nausea, Vomitus, dan Dispepsia. Dalam: Harrison, editor. Prinsip-Prinsip Ilmu Penyakit Dalam. Jakarta: Penerbit Buku Kedokteran EGC; 1999.

2. Siswanto W. Perkembangan Strategi dalam Pendekatan Penderita Dispepsia Non-Ulkus. Medika 1999;61:370-6.

3. Mahadeva S, Goh KL. Epidemiology of Functional Dyspepsia: A Global Perspective. World J Gastroenterol 2006;12(17):2661-6.

4. Sofian A. Kualitas Hidup Penderita Dispepsia Fungsional. Yogyakarta: Bagian/SMF IImu Penyakit Dalam Fakultas Kedokteran UGM/RSUP Dr. Sardjito;2001.

5. Fox JG, Dangler CA, Taylor NS, King A, Koh TJ, Wang TC. High-Salt Diet Induces Gastric Epithelial Hyperplasia and Parietal Cell Loss, and Enhances Helicobacter pylori Colonization in C57BL/6 Mice. Cancer Res 1999;59:4823-8.

6. Strumylaitë L, Dièkutë J, Dudzevièius J, Dregval L. SaltPreserved Foods and Risk of Gastric Cancer. Medicina (Kaunas) 2006;42(2):164-70.

7. Supadi S, Pramono D, Nawi. Statistika Kesehatan. Yogyakarta: Bagian IImu Kesehatan Masyarakat FK UGM; 2000.

8. Budiman H. Peranan Gizi pada Pencegahan dan Penanggulangan Hipertensi. Medika 1999;12:784-8.
Perlu penelitian lebih lanjut pula mengenai hubungan antara asupan natrium dan kalium dengan infeksi Helicobacter pylori dengan penegakan diagnosis infeksi menggunakan pemeriksaan yang tidak membutuhkan biaya terlalu mahal.

9. Almatsier S. Prinsip Dasar IImu Gizi. Jakarta: Penerbit PT Gramedia Pustaka Utama; 2002.

10. Baker G, Fraser RJ, Young G. Subtypes of Functional Dyspepsia. World J Gastroenterol 2006;12(17):266771.

11. Tahir H Hamid. Diagnosis dan Penatalaksanaan Dispepsia. Jurnal Medika Nusantara 2002;23(2):63842.

12. Tsugane S. Salt, Salted Food Intake, and Risk of Gastric Cancer: Epidemiologic Evidence. Cancer Sci 2005;96(1):1-6.

13. Daldiyono, Dharmika, Simadibrata M, Bardiman S. Nutrisi pada Penyakit Gastrointestinal. Yogyakarta: Penerbit Seminar Nutrisi Klinik Up-date;1998.

14. Smyth L. Diet For Ulcers and Gastritis. Healthtouch [serial online] 1995 [cited 2006 Nov 15]. Available from: http://www.healthtouch.com.

15. Mobley HLT, Island MD, Hausinger RP. Molecular Biology of Microbial Ureases. Microbiol Res 1995;59(3):45180.

16. Nurdjanah S. Penatalaksanaan Infeksi Helicobacter pylori. Dalam: Panitia Pertemuan IImiah Tahunan Penyakit Dalam, editor. Pertemuan IImiah Tahunan IImu Penyakit Dalam:1999;19-26.

17. Tsugane S, Tei Y, Takahashi T, Watanabe W, Sugano K. Salty Food Intake and Risk of Helicobacter pylori Infection. Jpn J Cancer Res 1994;85:474-8. 